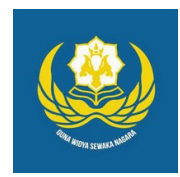

Jurnal Analogi Hukum

Journal Homepage: https://ejournal.warmadewa.ac.id/index.php/analogihukum

\title{
Sanksi Pidana Terhadap Tindak Pidana Aborsi (Studi Kasus Putusan Nomor : 87/Pid.G/2007/Pn.Gir)
}

\author{
Bujangga Agus Arif Pranata*, I Nyoman Sujana dan Diah Gayatri Sudibya \\ Universitas Warmadewa, Denpasar-Bali, Indonesia \\ *bujanggapranata@gmail.com
}

How To Cite:

Pranata, B, A, A., Sujana, I, N., Sudibya, D, G. (2020). Sanksi Pidana Terhadap Tindak Pidana Aborsi (Studi Kasus Putusan Nomor : 87/ Pid.G/2007/Pn.Gir). Jurnal Analogi Hukum, 2 (2). 148-154. Doi: https://doi.org/10.22225/ah.2.2.1891.148-154

\begin{abstract}
As part of criminal acts, it is a matter of abortion, namely: mainly among women who experience unwanted pregnancies choose the path for abortion with various risks, namely in the form of death or legal violation of the provisions in the Criminal Code. For example, it often happens that a woman intentionally causes death or death of her womb, or tells another person to cause it, she is sentenced to imprisonment for a maximum of four years, which is regulated in the Criminal Code (KUHP). Abortion is a prohibited act, so it is said to be a criminal act, because the threat of partial criminal law is regulated in the Criminal Code. The formulation of the problem in this study is: what is the background of the perpetrator committing an abortion crime and how is the criminal sanction imposed by the judge on the perpetrator of the crime of abortion. The type of research used in this study is normative legal research. The results of the discussion in this study are: The background of the perpetrators committing abortion crimes, namely from unmarried women (too young, girlfriends refusing to be responsible, not planning to marry a boyfriend, fear of parents, maintaining a good family name and tradition) and those who have gotten married (contraceptive failure, is in the process of divorce, and the husband is not responsible). Criminal sanctions imposed by judges on perpetrators of abortion crimes, namely in the Criminal Code, the perpetrators and those who assist in the occurrence of abortion are charged with Article 346 to Article 349.
\end{abstract}

Keywords: Abortion and legislation, criminal Sanctions,

\begin{abstract}
Abstrak-Sebagai bagian dari perbuatan pidana, adalah masalah tindakan aborsi yaitu: banyak diantara perempuan yang mengalami kehamilan yang tidak dikehendaki memilih jalan untuk aborsi dengan berbagai resiko, yaitu berupa kematian atau pelanggaran hukum terhadap ketentuan dalam KUHP. Seperti contoh sering terjadi seorang wanita dengan sengaja menyebabkan gugur atau mati kandungannya, atau menyuruh orang lain menyebabkan itu, dia dipidana dengan pidana penjara selama-lamanya empat tahun, dimana hal tersebut telah diatur dalam Kitab Undang-Undang Hukum Pidana (KUHP). Aborsi sebagai perbuatan yang dilarang, sehingga dikatakan sebagai perbuatan pidana, karena ancaman hukum pidana sebagian diatur dalam KUHP. Rumusan masalah dalam penelitian ini adalah: 1. apakah yang melatarbelakangi pelaku melakukan tindak pidana aborsi dan 2. bagaimanakah sanksi pidana yang dijatuhkan oleh hakim terhadap pelaku tindak pidana aborsi. Tipe penelitian yang dipergunakan dalam penelitian ini adalah penelitian hukum normatif. Hasil pembahasan dalam penelitian ini adalah:Latar belakang pelaku melakukan tindak pidana aborsi yaitu dari perempuan yang belum menikah (terlalu muda, pacar menolak bertanggung jawab, tidak berencana menikah dengan pacar, takut orang tua, menjaga nama baik keluarga, dan tradisi) dan yang sudah menikah (kegagalan kontrasepsi, sedang dalam proses bercerai, dan suami tidak bertanggung jawab). Sanksi pidana yang dijatuhkan oleh hakim terhadap pelaku tindak pidana aborsi yaitu dalam KUHP, pelaku dan yang membantu terjadinya tindakan aborsi dijerat dengan Pasal 346 sampai dengan Pasal 349.
\end{abstract}

Kata Kunci: Aborsi dan peraturan perundang-undangan, sanksi pidana

\section{Pendahuluan}

Keadilan hukum bagi hak masyarakat harus dijamin dan dilindungi oleh negara. Hak untuk mendapatkan keadilan hukum sama derajatnya dengan hak masyarakat untuk mendapatkan keadilan sosial, politik, dan ekonomi. Namun dalam praktiknya, masyarakat miskin, 
masih sulit untuk mendapatkan akses terhadap keadilan hukum. Akses tersebut adalah jalan yang dilalui oleh masyarakat untuk menggapai keadilan di luar maupun di dalam pengadilan.

Seperti misalnya masalah hukum pidana di Indonesia, salah satu masalah pokok dalam hukum pidana yang sering menjadi perdebatan para ahli hukum adalah masalah pidana, disamping masalah pokok yang lain yaitu masalah tindak pidana dan masalah kesalahan. Hukum pidana di Indonesia saat ini dirasakan kurang memenuhi suatu keadilan serta ketentraman dalam kehidupan bermasyarakat, sebab banyaknya suatu tindak pidana yang terjadi akhir-akhir ini menjadikan hukum itu tidak lagi sebagai kontrol sosial melainkan banyaknya orang-orang tertentu memanfaatkan hukum sebagai corong untuk berbuat kejahatan, ini disebabkan kurangnya efek jera yang ditimbulkan oleh hukum pidana itu sendiri (Harefa, 2020). Ketiga masalah pokok tersebut masingmasing mempunyai persoalan-persoalannya sendiri, yang satu sama lain berkaitan erat dengan persoalan dasar manusia yakni hak-hak asasi manusia (Muladi, 1995).

Masalah pidana akan menimbulkan persoalan-persoalan tentang pemberian pidana serta tentang masalah-masalah tindak pidana akan menyangkut persoalan kriminalisasi dan dekriminalisasi dengan segala syarat-syarat yang terkandung didalamnya. Sedang masalah kesalahan akan menyangkut berbagai persoalan yang sangat rumit. Misalnya saja tentang subyek hukum pidana berupa korporasi dan masalah strict liability (suatu bentuk pertanggungjawaban yang tidak memerlukan adanya kesalahan) yang sampai saat ini belum terpecahkan dalam hubungannya dengan penyusunan Usul KUHP Baru (Muladi, 1995).

Berkaitan dengan persoalan pidana ini, Sudarto menyatakanbahwa :

Dua hal yang sangat penting dalam hukum pidana adalah syarat-syarat untuk memungkinkan penjatuhan pidana. Apabila hal yang pertama itu diperinci lebih lanjut, maka dapat dikatakan bahwa hukum (maksudnya hukum pidana) ada tiga pokok persoalan : Pertama, tentang perbuatan yang dilarang. Kedua, tentang orang yang melanggar larangan itu, Ketiga tentang pidana yang diancam pada si pelanggar itu.

Masalah pidana merupakan masalah yang sangat sensitif, mengingat masalah tersebut sangat erat bersinggungan dengan harkat martabat manusia. Lebih-lebih pada masa sekarang ini dimana tuntutan akan pengakuan dan penghormatan terhadap hak asasi manusia sangat menonjol sebagai akibat munculnya arus demokrasi dan globalisasi. Masalah pidana menjadi semakin urgen dibicarakan dan orang mulai melihat pidana sebagai primadona dalam pembicaraan (Muladi, 1995).

Kesadaran terhadap semakin pentingnya diskusi tentang pidana dan pemidanaan nampak dari pendapat-pendapat yang pada intinya menyatakan, bahwa bagian yang terpenting dari KUHP suatu bangsa adalah stelsel pidananya, sebab dari stelsel pidana ini akan tercermin nilai nilai sosial budaya bangsa tersebut (Muladi, 1995).

Dengan demikian dapat dikatakan, tiga masalah pokok tersebut yaitu tindak pidana, kesalahan dan pidana merupakan masalah sentral dalam hukum pidana. Dalam perjalanan sejarahnya, ketiga masalah tersebut selalu menjadi kajian yang aktual seiring dengan perkembangan peradaban masyarakatnya. Bahkan sampai sekarangpun ketiga pokok masalah tersebut menjadi bahan kajian utama dalam hukum pidana. Khususnya mengenai masalah pidana terdapat dua pandangan yang berhadapan.

Keberatan terhadap penggunaan sanksi (hukum) pidana sebagai sarana penanggulangan kejahatan dalam masyarakat, dan sebagian ahli yang lain tetap mendukung digunakannya sanksi pidana dalam masyarakat, meskipun dengan berbagai catatan (Waluyo, 2000).

Sebagai bagian dari perbuatan pidana, adalah masalah tindakan aborsi yaitu:

Banyak diantara perempuan yang mengalami kehamilan yang tidak dikehendaki memilih jalan untuk aborsi dengan berbagai resiko, yaitu berupa kematian atau pelanggaran hukum terhadap ketentuan dalam KUHP. Seperti contoh sering terjadi seorang wanita dengan sengaja menyebabkan gugur atau mati kandungannya, atau menyuruh orang lain menyebabkan itu, dia dipidana dengan pidana penjara selama-lamanya empat tahun, dimana hal tersebut telah diatur dalam Kitab UndangUndang Hukum Pidana (KUHP). Aborsi sebagai perbuatan yang dilarang, sehingga dikatakan sebagai perbuatan pidana, karena ancaman hukum pidana sebagian diatur dalam KUHP.

Pasal 346 KUHP dijelaskan bahwa, yang dapat diancam hukum pidana dalam Pasal ini adalah:

Wanita yang dengan sengaja menyebabkan kandungannya menjadi gugur atau mati, atau 
Wanita yang dengan sengaja menyuruh orang lain menyebabkan kandungannya menjadi gugur atau mati.

Pengguguran kandungan atau pembunuhan janin yang ada di dalam kandungan dapat dilakukan dengan bermacam-macam cara, misalnya, dengan obat yang diminum atau dengan alat yang dimasukkan ke dalam rahim melalui lubang kemaluan wanita.

Berdasarkan latar belakang tersebut diatas, maka dapat dirumuskan permasalahan dalam pertanyaan penelitian berikut ini:

Apakah yang melatarbelakangi pelaku melakukan tindak pidana aborsi?

Bagaimanakah sanksi pidana yang dijatuhkan oleh hakim terhadap pelaku tindak pidana aborsi?

Secara umum penelitian ini dilakukan untuk mengetahui sanksi pidana terhadap tindak pidana aborsi sesuai dengan peraturan perundang-undangan yang mengaturnya sedangkan secara khusus penelitian ini bertujuan untuk:

Untuk mengetahui yang melatarbelakangi pelaku melakukan tindak pidana aborsi.

Untuk mengetahui sanksi pidana yang dijatuhkan oleh hakim terhadap pelaku tindak pidana aborsi.

Tipe penelitian yang dipergunakan dalam penyusunan skripsi ini adalah penelitian hukum normatif. Yaitu dengan menguraikan permasalahan-permasalahan yang ada yang selanjutnya dibahas dan dikaji berdasarkan teori -teori hukum dan kemudian dikaitkan dengan peraturan perundang-undangan yang berlaku dalam praktek hukum. Dalam penelitian ini digunakan pendekatan perundang-undangan (statue approach) dan pendekatan konseptual (conseptual approach).

\section{Metode}

Didalam penulisan ini terdapat bahanbahan hukum yang terdiri dari: (1) Bahan hukum primer yaitu bahan-bahan hukum yang mengikat, meliputi : Undang-Undang Dasar Negara Republik Indonesia Tahun 1945, Kitab Undang-Undang Hukum Pidana (KUHP), Undang-Undang Nomor 8 Tahun 1981 tentang Kitab Undang-Undang Hukum Acara Pidana (KUHAP) dan Undang-Undang Nomor 36 Tahun 2009 Tentang Kesehatan. Bahan hukum sekunder berupa semua publikasi tentang hukum yang bukan merupakan dokumendokumen resmi. Publikasi tentang hukum meli- puti buku-buku teks, kamus-kamus hukum, jurnal-jurnal hukum, dan komentar-komentar atas putusan hukum (Marzuki, 2007).

Pengumpulan bahan hukum dilakukan dengan cara membaca, mempelajari, memahami, dan menganalisis buku atau literatureliteratur, ketentuan perundang-undangan, makalah-makalah, majalah-majalah, ataupun informasi dalam bentuk lain seperti yang diperoleh dari internet, yang berhubungan erat dengan obyek kajian atau materipenelitian, kemudian dilakukan pencatatan dan pengutipan bagianbagian yang penting.

\section{Hasil Penelitian Dan Pembahasan}

Indonesia tidak termasuk negara yang menjadikan aborsi sebagai metode keluarga berencana. Sebaliknya, Indonesia justru mengambil posisi hukum yang paling keras, yaitu melarang semua aborsi untuk semua alasan, kecuali untuk menyelamatkan nyawa ibu (disebut abortus provokatos medikalis atau terapetikus).

Pengertian dari aborsi di kalangan ahli ada dua jenis pengertian yaitu, Abortus alamiah dan abortus buatan. Abortus alamiah adalah mekanisme alamiah yang menyebabkan terhentinya proses kehamilan sebelum berumur 28 minggu, sedangkan yang dimaksud Abortus buatan adalah suatu upaya yang disengaja untuk menghentikan proses kehamilan sebelum berumur 28 minggu, dimana janin (hasil konsepsi) yang dikeluarkan tidak dapat bertahan hidup diluar. Meski aborsi untuk alasan di luar menyelamatkan nyawa ibu diperlakukan sebagai perbuatan kriminal (disebut abortus provokatus kriminalis), insiden aborsi di Indonesia tergolong sangat tinggi. Utomo dkk memperkirakan bahwa sekitar 2 juta perempuan Indonesia mengakhiri kehamilannya dengan aborsi, dan sebagian besar di antarnya adalah aborsi yang tidak aman (Darwin, 2005).

Estimasi Utomo ini lebih tinggi dibandingkan dengan estimasi-estimasi yang dibuat sebelumnya. Widyantoro (1990) membuat estimasi aborsi sebesar 700.0001.000.000, Tjitarsa (1993) memperkirakan sebesar 1.500.000, dan Affandi (2000) juga memperkirakan sebesar 1,5 juta. Angka ini terdiri dari aborsi disengaja karena kegagalan KB sebesar 0,6 juta dan karena tidak memakai KB sebesar 0,7 juta. Di sini tidak termasuk aborsi spontan (abortus spontaneus) yang diperkirakan Affandi sebesar 1 juta sehingga jika kedua jenis aborsi itu digabung angkanya menjadi 2,3 juta. 
Angka kejadian 2 juta kasus per tahun pada estimasi Utomo berarti 37 aborsi per 1,000 wanita usia 15-49 tahun, atau 43 aborsi per 100 kelahiran hidup, atau 30 persen dari kehamilan. Proporsi aborsi 30 persen dari kehamilan ini lebih tinggi dibandingkan dengan pada tingkat global. Seperti diketahui, angka kejadian aborsi di dunia diperkirakan 46 juta kasus pada tahun 1995 atau 25,6 persen dari 180 juta kehamilan pada tahun yang sama.

Aborsi sebanyak itu sebagian besar dilakukan untuk alasan di luar yang diperkenankan oleh undang-undang. Affandi (2000) mengindentifikasi sejumlah alasan utama, yaitu ekonomi, kehamilan di luar nikah, korban pemerkosaan dan incest. Utomo (2002) menemukan sejumlah alasan dominan, yaitu jumlah anak sudah cukup, terlalu tua untuk melahirkan; tidak siap menikah karena masih sekolah, dan belum siap punya anak. Sementara itu Habsjah (2002) membedakan alasan dominan dari perempuan yang belum menikah (terlalu muda, pacar menolak bertanggung jawab, tidak berencana menikah dengan pacar, takut orang tua, menjaga nama baik keluarga, dan tradisi) dan yang sudah menikah (kegagalan kontrasepsi, sedang dalam proses bercerai, dan suami tidak bertanggung jawab).

Seluruh alasan implisit atau eksplisit yang terkait dengan keinginan untuk membatasi jumlah anak. Dengan begitu kita bisa mengatakan bahwa dari sudut pandang sosial demografis aborsi sesungguhnya telah secara luas dipraktikkan di Indonesia sebagai metode pengendalian kelahiran. Data ini juga memberi pelajaran penting bagi pengambil kebijakan bahwa hukum aborsi yang sangat restriktif ternyata gagal menyurutkan niat dari banyak perempuan yang mengalami kehamilan yang tidak kehendaki untuk mengakhiri kehamilannya.

Persoalannya adalah ketika hukum tidak memberi tempat bagi pelayanan aborsi yang aman, maka para perempuan yang mengalami kehamilan tidak dikehendaki dan yang karena alasan tertentu tidak ingin melanjutkan kehamilannya, terpaksa harus pergi ke penolong aborsi yang tidak memiliki kompetensi untuk memberi pertolongan secara aman, misalnya ke bidan atau dukun aborsi, dengan risiko mengalami komplikasi kesehatan, bahkan kematian.

Seperti diketahui bahwa angka kematian maternal di Indonesia masih tinggi, bahkan tertinggi di Asia, dan kurang lebih 11 persen di antaranya terjadi karena pertolongan aborsi yang tidak aman. Data tahun 1995 menunjukkan bahwa 600.000 perempuan mati karena kehamilan dan persalinan (SKRT 1995). Dari angka tersebut, 66.000 mati karena aborsi (Darwin, 2005).

Kekhawatiran dari pihak yang menolak legalisasi aborsi adalah kemungkinan naiknya angka aborsi setelah praktik seperti itu dilegalkan. Secara empiris hal seperti itu tidak selalu terbukti. Memang ada contoh negara yang melegalkan aborsi dan jumlah praktik aborsi tetap tinggi, yaitu Cina. Tingginya angka aborsi di sana lebih disebabkan oleh sikap proaktif pemerintah Cina membatasi pasangan di Cina untuk hanya boleh mempunyai satu anak. Akan tetapi, di negara-negara lain, contohnya Jepang dan Singapura, legalisasi aborsi menimbulkan dampak yang berbeda. Di kedua negara tersebut, aborsi mengalami peningkatan pada beberapa tahun pertama, tetapi dalam kurun waktu berikutnya mengalami penurunan secara konsisten.

Singapura melegalkan aborsi tahun 1967, dan angka aborsi di negara itu mengalami kenaikan setelah itu. Namun kenaikan tersebut berlangsung hanya sampai tahun 1985, yaitu dari 1.913 menjadi 23.512 kejadian. Setelah itu, angka aborsi mengalami penurunan secara konsisten setiap tahunnya menjadi 17.073 pada tahun 1992. Di Jepang, legalisasi aborsi terjadi pada tahun 1948, dan angka aborsi mengalami kenaikan secara konsisten dari 246.104 pada tahun 1949 menjadi 1.170 .143 pada tahun 1955 . Akan tetapi, sejak tahun 1956, angka aborsi mengalami penurunan secara konsisten setiap tahunnya sehingga pada tahun 1999 hanya sebanyak 446.876 kejadian. Penurunan angka aborsi setelah legalisasi ini terjadi karena meluasnya pemakaian kontrasepsi.

Secara teoritis dapat dikatakan bahwa tinggi rendahnya aborsi tidak secara langsung berkaitan dengan status hukum praktek aborsi, tetapi keterkaitan antara variabel nilai anak, angka fertilitas, dan penggunaan kontrasepsi. Jika rata-rata pasangan suami-istri pada suatu masyarakat mengharapkan jumlah anak yang banyak, maka angka fertilitas (jumlah anak) di masyarakat tersebut akan cenderung tinggi. Dalam keadaan seperti ini dorongan untuk menunda kehamilan menjadi rendah sehingga angka penggunaan kontrasepsi juga rendah.

Ketika masyarakat tersebut mengalami perubahan sosial, khususnya jika terjadi perubahan nilai anak menuju pada keinginan mempunyai anak sedikit, maka keinginan menggunakan kontrasepsi juga akan meningkat. Akan tetapi, jika di masyarakat tersebut belum cukup tersedia kontrasepsi atau jika banyak 
terjadi kegagalan kontrasepsi, maka angka fertilitas masih akan tetap tinggi. Jika angka fertilitas lebih tinggi dibandingkan dengan harapan jumlah anak hidup, maka di dalam masyarakat tersebut terjadi masalah kehamilan tidak dikehendaki. Tingginya kehamilan yang tidak dikehendaki akan memberi dorongan bagi sejumlah pasangan untuk mengakhiri kehamilan, yaitu dengan melakukan aborsi. Oleh karena itu, kenaikan angka aborsi merupakan indikasi dari adanya perubahan nilai anak yang tidak diikuti serta secara sebanding dengan ketersediaan dan efektivitas penggunaan kontrasepsi.

Ketika terjadi legalisasi aborsi, angka aborsi dapat mengalami kenaikan. Kenaikan ini dapat terjadi karena beberapa alasan.

Pertama, mereka yang mengalami kehamilan tidak dikehendaki menjadi lebih melakukan aborsi karena tidak ada konsekuensi hukum dari tindakan tersebut. Kedua, kenaikan itu terjadi karena sistem pelaporan yang lebih baik. Artinya, sebelum ada legalisasi praktik aborsi sudah banyak terjadi, tetapi banyak yang dilakukan secara sembunyi-sembunyi. Setelah ada legalisasi, semua praktik aborsi dapat dicatat dan dilaporkan tanpa risiko hukum. Dengan begitu, kenaikan angka aborsi tidak mencerminkan adanya kenaikan insiden aborsi yang sebenarnya. Dengan kata lain, yang terjadi hanya pergeseran status aborsi, dari aborsi ilegal menjadi aborsi legal, sementara insiden aborsi sesungguhnya tidak mengalami peningkatan. Ketiga, angka aborsi naik karena legalisasi aborsi tidak diikuti dengan peningkatan efektivitas penggunaan kontrasepsi. Sementara itu di masyarakat tersebut terjadi perubahan yang signifikan dalam nilai anak. Karena banyak pasangan suami istri ingin membatasi jumlah kehamilan tapi gagal melakukannya karena kendala kontrasepsi, terjadilah kehamilan tidak dikehendaki. Inilah pada gilirannya meningkatkan angka aborsi (Darwin, 2005).

Namun dalam perkembangan kemudian, angka aborsi dapat menurun jika di masyarakat tersebut terjadi peningkatkan efektivitas penggunaan kontrasepsi. Pada masyarakat dengan efektivitas penggunaan kontrasepsi paripurna (perfect contraceptie society), angka aborsi akan menjadi nol. Dengan kata lain, peningkatan efektivitas penggunaan kontrasepsi merupakan metode paling efektif untuk mengurangi angka aborsi pada masyarakat.

Oleh karena itu, tampaknya negara perlu melakukan peninjauan ulang tentang posisi hukumnya dalam menyikapi masalah kemanusiaan yang sangat memprihatinkan ini. Secara garis besar ada alternatif posisi hukum terhadap praktik aborsi. Pertama adalah sangat restriktif. Di sini aborsi dilarang untuk semua alasan, kecuali untuk menyelamatkan jiwa ibu. Inilah posisi yang diambil Indonesia dan beberapa negara lain, seperti Filipina, Srilanka, dan Saudi Arabia. Kedua, angka restriktif. Di sini aborsi pada dasarnya juga dilarang, tetapi toleransi hukum diberikan terhadap kondisi yang sangat khusus di luar alasan menyelamatkan nyawa ibu, yaitu gangguan fisik dan mental dari ibu hamil jika kehamilan diteruskan, janin yang cacat sehingga akan menimbulkan penderitaan yang tidak tertanggungkan bagi bayi jika lahir, dan perempuan yang hamil karena diperkosa atau hasil dari incest. Malaysia dan Thailand masuk dalam kategori ini. Ketiga adalah agak longgar. Di sini aborsi dibolehkan untuk alasan yang lebih luas lagi, seperti alasan ekonomi (ketidakmampuan ekonomi ibu merawat dan membesarkan bayi), jumlah anak sudah dianggap cukup, usia ibu hamil terlalu muda atau tua (risiko tinggi), dll. Termasuk dalam kategori ini adalah Bulgaria, Inggris, Australia, India dan Jepang. Keempat adalah sangat longgar. Di sini aborsi dibolehkan atas permintaan ibu hamil karena semua alasan. Termasuk dalam kategori ini, antara lain, adalah Amerika Serikat, Prancis, Italia, Belanda, Tunisia, Turki dan Singapura.

Tanpa adanya keberanian untuk mengubah posisi hukumnya ke arah yang lebih longgar, maka ke depan perempuan akan dalam kondisi yang sama rentannya atau lebih rentan lagi, yaitu mengalami komplikasi karena praktik aborsi yang tidak aman.

Aborsi seperti dijelaskan di atas merupakan perbuatan yang banyak mengundang kontroversi karena di dalamnya terkandung konflik nilai yang sulit didamaikan. Namun negara harus mengambil sikap tertentu terhadap masalah yang sangat dilematis ini. Dalam menentukan pilihan pertimbangan moral merupakan pertimbangan penting, bagaimana pun aborsi memang berhubungan dengan kesadaran moral masyarakat. Namun pertimbangan moral bukanlah satu-satunya pertimbangan. Perlu juga dilihat implikasi sosial yang lebih luas dari pilihan kebijakan yang diambil, apakah pilihan tersebut mendatangkan manfaat sosial yang lebih besar dari kerugiannya, atau sebaliknya. Di sinilah memang dilema dalam pengambilan keputusan acap kali terjadi. Pengambil kebijakan tidak dihadapkan kepada dua pilihan dengan prefensi nilai yang sederhana yang jelas, yaitu antara 
alternatif kebijakan yang baik (mendatangkan manfaat tanpa kerugian) dan yang jelek (mendatangkan kerugiaan tanpa manfaat), tetapi antara pilihan-pilihan kebijakan yang menimbulkan trade off, atau antara alternatif yang jelek dan alternatif yang jelek dan alternatif lain yang lebih jelek lagi.

Pertama perlu disadari bahwa aborsi bukanlah merupakan pilihan yang ideal yang sedapat mungkin dihindari. Perlu diambil langkah-langkah preventif agar kondisi yang menimbulkan terjadi kehamilan tidak dikehendaki dapat dikurangi sehingga perempuan terhindar dari dorongan untuk melakukan aborsi. Tindakan preventif yang dimaksud adalah pengendalian terhadap kecenderungan seks bebas, prostitusi pemerkosaan, incest, dan sebagainya. Kegagalan kontrasepsi pun diupayakan seminimal mungkin. Namun harus diakui bahwa bagaimanapun intensifnya kita melakukan tindakan preventif seperti tersebut di atas, kita tidak mungkin dapat mengeliminasinya sama sekali. Pada tingkat tertentu masyarakat pasti mempunyai masalahmasalah seperti tersebut di atas. Oleh karena itu, kehamilan tidak dikehendaki pada tingkat tertentu pasti terjadi.

Terhadap kehamilan yang tidak dikehendaki ini perlu diupayakan agar perempuan menghindarkan diri dari keputusan melakukan aborsi. Di sinilah pentingnya lembaga advokasi yang sedapat mungkin melibatkan ahli kandungan, ahli jiwa, dan ahli agama. Klinik-klinik kesehatan yang sering didatangi pasien yang meminta pelayanan aborsi perlu pula dilengkapi dengan pelayanan advokasi yang secara sungguh-sungguh memberikan bimbingan kepada klien yang mengalami kehamilan tak dikehendaki untuk tidak melakukan aborsi.

Dalam KUHP, pelaku dan yang membantu terjadinya tindakan aborsi dijerat dengan Pasalpasal 346-349. Berbagai pendapat dikemukakan tentang kelemahan Pasal 346 sampai 349 KUHP, yaitu: Pertama, pasal-pasal tersebut dimasukan dalam Bab Penghilangan Nyawa, sedangkan dalam penghentian kehamilan belum tentu terjadi penghilangan nyawa. Menurut definisi aborsi secara medis, terdapat pembatasan usia kehamilan seperti dijelaskan oleh seorang ahli kebidanan dan kandungan sebagai berikut.

Pertama, pasal-pasal tersebut dimasukkan dalam Bab Penghilangan Nyawa, sedangkan dalam penghentian kehamilan belum tentu terjadi penghilangan nyawa. Menurut definisi aborsi secara medis, terdapat pembatasan usia kehamilan seperti dijelaskan oleh seorang ahli kebidanan dan kandungan sebagai berikut : Aborsi adalah penghentian kehamilan pada usia nama janin tidak dapat hidup di luar kandungan, yaitu pada usia kurang dari 20 minggu dan berat kurang dari 500 gram (Wignyosastro, 2003).

Oleh karena itu, bila tindakan pengguguran kandungan dilakukan pada usia di atas 20 minggu, tidaklah disebut aborsi, dan secara medis memang janin tidak dapat hidup di luar kandungan. Dalam hal ini bukan berarti terjadi penghilangan nyawa.

Kedua, KUHP ini tidak melihat alasan mengapa terjadi pengguguran kandungan. Artinya, perempuan pemilik tubuh, tidak pernah ditanya mengapa dia melakukan tindak aborsi. Banyak penelitian memperlihatkan bahwa tidak ada satu pun data yang menunjukkan, bahwa perempuan yang melakukan tindakan aborsi itu, melakukannya dengan senang hati. Bahkan beban psikologis terasa sangat berat apabila dia harus memutuskan dan melakukan tindakan aborsi.

Dalam lokakarya tentang Pemahaman Kesehatan Perempuan yang diselenggarakan oleh Convention Watch bekerja sama dengan Direktorat Reserse Mabes Polri tahun 1993, diajukan pertanyaan oleh Polisi Reserse, peserta lokakarya, tentang pendekatan apa yang dilakukan aparat hukum agar dapat memberikan keadilan pada perempuan dalam kasus aborsi.

Diberikan jawaban oleh Tapi Omas Ihromi, Guru Besar Ilmu Hukum, untuk menggunakan pendekatan oportunitas, yang berarti bahwa penegak hukum harus memberi kesempatan kepada perempuan yang melakukan tindakan aborsi itu untuk membela diri, mengapa dia harus melakukan tindakan aborsi tersebut. Hal tersebut akan dapat menjadi bahan pertimbangan aparat hukum dalam memutus perkara (Ihromi, 2003).

Ketiga, Undang-undang (KUHP) ini tidak mempertimbangkan bahwa teknologi sudah jauh berkembang dibandingkan ketika undangundang ini diberlakukan. Menurut Ahli Kebidanan dan Kandungan, pada saat ini aborsi sudah dapat dilakukan dengan cara menggunakan kemajuan teknologi kedokteran yang sangat sederhana dan aman, dalam arti tingkat kegagalannya sangat kecil. Bahkan aborsi yang dilakukan oleh tenaga profesional dan terlatih di tempat yang memenuhi standar serta pada usia awal kehamilan kurang dari 12 minggu, tingkat keamanannya jauh lebih besar dibandingkan bila perempuan tersebut harus 
melanjutkan kehamilannya sampai persalinan. Batasan kehamilan sampai usia kurang dari 12 minggu, penghentian kehamilan dapat dilakukan dengan metode aspirasi vakum (Vacuum aspiration). Metode MVA ini selain murah dan mudah dilakukan, efektivitasnya juga cukup tinggi, yaitu bisa mencapai $99 \%$.

Dari definisi tentang tindakan aborsi atau menggugurkan kandungan di atas, jelaslah bahwa, bila terjadi pengguguran, tetapi janin bisa hidup, bukanlah disebut sebagai keguguran atau aborsi melainkan kelahiran prematur dan beratnya pasti di atas 500 gram. Bila pengguguran dilakukan di atas 20 minggu, dan janinnya mati, bukan disebut sebagai pengguguran, melainkan infantiside atau pembunuhan janin. Jadi, permasalahan terletak pada kapan kehidupan itu terjadi? Atau kapan disebut pembunuhan nyawa janin? Masalahnya sendiri memang pelik, bila dilihat dari pasalpasal di atas, karena aparat hukum mengacu pada mematikan kandungan, persoalannya, kapan kandungan itu ada (Lukman, 2004).

Sampai saat ini para ahli hukum belum pernah mengadakan pertemuan, atau seminar untuk membahas, kapan terjadi kehamilan (kapan kandungan itu ada). Bila para ahli hukum membahas hal tersebut akan ada suatu kepastian hukum. Demikian pula para tokoh agama, perlu melakukan pembahasan karena masih ada perbedaan persepsi antara para ahli medis, ahli agama dengan para ahli hukum.

\section{Simpulan}

Berdasarkan uraian tersebut diatas dapatlah ditarik simpulan sebagai berikut :

Latar belakang pelaku melakukan tindak pidana aborsi yaitu dari perempuan yang belum menikah (terlalu muda, pacar menolak bertanggung jawab, tidak berencana menikah dengan pacar, takut orang tua, menjaga nama baik keluarga, dan tradisi) dan yang sudah menikah (kegagalan kontrasepsi, sedang dalam proses bercerai, dan suami tidak bertanggung jawab).

Sanksi pidana yang dijatuhkan oleh hakim terhadap pelaku tindak pidana aborsi yaitu dalam KUHP, pelaku dan yang membantu terjadinya tindakan aborsi dijerat dengan Pasal 346 sampai dengan Pasal 349.

Sesuai dengan kesimpulan tersebut diatas, dapat penulis sampaikan.

\section{Daftar Pustaka}

Darwin, M. M. (2005). Negara dan Perempuan
Reorientasi Kebijakan Publik. Yogyakarta: CV. Adipura.

Harefa, S. (2020). Penegakan Hukum Terhadap Tindak Pidana Di Indonesia Melaui Hukum Pidana Positif Dan Hukum Pidana Islam. University of Bengkulu Law Journal, 5(1), 35-58. Retrieved from https://ejournal.unib.ac.id/ index.php/ubelaj/article/view/7303

Ihromi, T. O. (2003). Prosiding Lokakarya Pemahaman Kesehatan Reproduksi Perempuan. Jakarta: Kerjasama Convention Watch dengan Direktorat Reserse, Mabes Polri.

Lukman, L. (2004). Permasalahan Aborsi dalam Undang-Undang Kesehatan Nomor 23 Tahun 1992 dan KUHP. Makalah Dalam Majalah Obstetri Dan Ginekologi Indonesia. Retrieved from Yayasan Bina Pustaka Srwono Prawirohardjo

Marzuki, P. M. (2007). Penelitian Hukum. Jakarta: Kencana Prenada Media Gru.

Muladi. (1995). Kapita Selekta Sistem Peradilan Pidana. Semarang: Badan Penerbit Universitas Diponegoro.

Waluyo, B. (2000). Pidana dan Pemidanaan. Jakarta: Sinar Grafika.

Wignyosastro, G. (2003). Hasil Diskusi Lokakarya Penghentian Kehamilan Tak Dikehendaki. In Hasil Diskusi Lokakarya Penghentian Kehamilan Tak Dikehendaki. Jakarta. 